\title{
Desulphurization of flue gases using waste of a water treatment plant
}

\author{
J. Vales, P. Sedlacek, S. Macek, L. Chytka \& J. Durik \\ Department of Research and Development, Brown Coal Research, \\ Institute, j.s.c., Czech Republic
}

\begin{abstract}
All activities in a technically developed society are accompanied by waste generation. The question of its removal or consequent environment friendly and economic use has been dealt with by mankind since the early 1990s. The target of a common international project worked on by the Investex Group, a.s. companies and the Research Institute for Brown Coal, the joint-stock company, is to look for ways to use the sludge from waste water treatment plants as an alternative resource for additive agent fabrication. Suitable waste treatment sludge for the additive agent preparation applied in the combustion of lower quality fossil fuels with a higher content of sulphur is generated as waste in ammonia fabrication from the sludge produced by municipal waste water treatment plants. The procedure in the agent fabrication from waste treatment sludge, the course of the combustion tests and the results of a theoretical level of desulphurization form the content of this paper.
\end{abstract}

Keywords: water treatment plant, lignite, desulphurization limestone.

\section{Introduction}

One of the important sources of energy in the Czech Republic is still the burning of coal. In order to reduce pollution, it is necessary to reduce the amount of harmful substances from burning coal, in different ways. Large energy sources, such as power plants, use combustion gas cleaning. One of the main harmful substances that is being removed is sulphur dioxide. Its concentration in combustion gas is directly proportional to the sulphur content in the coal being burned. During the burning of coal in fluid boilers, a desulphurization additive is added to the fluid bed - mostly limestone or dry hydrate which causes part of the 
sulphur dioxide to react with limestone ions to produce calcium sulphate. This calcium sulphate becomes a part of the ash. When using sufficient amounts of a desulphurization agent, the concentration of sulphur dioxide in the combustion gas will be reduced accordingly. Using the already-mentioned desulphurization additives, this represents a method for reducing the sulphur dioxide load on the environment, but also increases costs for energy production. In terms of cost reduction it is necessary to find new types of additives, which have a similar efficiency, but are not so financially demanding. One such additive could be the modified sludge of wastewater treatment plants which is stabilized by means of limy ions. Such sludge contains a certain amount of useful energy and can contain a significant proportion of limy ions, depending on the modification method used. The aim of this study was to verify in the lab the desulphurization activity of three types of stabilized sludge (prepared using different stabilization methods) and to evaluate their suitability as a desulphurization additive for fluid burning of the Most region brown coal.

\section{Properties of the modified sludge of a waste water treatment plant}

Sludge from a waste water treatment plant has limited potential for further use so far. To be able to use it further, the sludge stabilization method is used, with the help of limy ions. Due to the increasing alkalinity of sludge as a result of adding lime ( $\mathrm{pH}$ values mostly over 12) pathogenic organisms are liquidated during sludge processing.

Appropriate sludge for the preparation of additives applicable by combustion processes of poorer quality fossil fuels with increased levels of sulphur is produced as waste of ammonia production of sludge which is produced in communal wastewater treatment plants. Ammonia is produced as a result of the chemical reaction when ammonia salt contained in produced sludge and hydrated lime (which is oversupplied) are mixed. After this reaction, the waste sludge containing useful energy substances and a surplus of lime ions is used as material for the preparation and production of additives. During the combustion process, the additives are necessary for binding the rising gaseous sulphur dioxide and converting it to solid calcium sulphate, which stays in the ash.

For the lab tests three wastewater treatment plant sludge samples were prepared in cooperation with a Slovak company INVESTEX-GROUP s.r.o (marked as ADK1 to ADK3), stabilized by means of limy ions. The prepared samples differed in their production method, amount and type of limy agents used. The recipe of sample preparation is obvious in Table 1. For preparation of samples, common types of agents were used for addition of Czech brown coal.

As the suggested new additive contains a certain amount of high-energy particles lab analyses were made of the prepared samples, whereby the basic parameters of these samples were determined; calorific value, ash content, water content and sulphur content. The results of these analyses are shown in the Table 2 . 
After burning the contents of effective components in the prepared samples were determined. It was the content of free $\mathrm{CaO}$ and total content of carbonates. These values of individual samples were compared with values of normally used additives, mostly then of limestone from Č́žkovice, which is added at the coal treatment plant Komořany. Due to different recipes, the modified samples differ in the content of limy ions. The highest concentration of limy ions was found in sample ADK 1 and was comparable with the concentration of these ions in a commonly-used desulphurization additive used in fluid combustion which is the limestone from Cížkovice with a of $\mathrm{CaO}$ of approximately $40 \%$. In the second sample of modified sludge ADK2, the concentration of limy ions was approximately a third lower than in the first sample. In the third sample ADK3 the concentration of limy ions was approximately three times lower than in the sample ADK1. The free $\mathrm{CaO}$ and total carbonate content analysis results are stated in the Table 3.

Based on this information, recipes for mixtures for lab burning tests were suggested. An overview of suggested recipes is stated in Table 5. In Figure 1 prepared sludge marked as ADK2 is shown.

Table 1: $\quad$ Receipt of sludge modified for addition.

\begin{tabular}{|l|c|c|c|}
\hline Sample & $\begin{array}{c}\text { Sludge } \\
{[\% \text { weight] }}\end{array}$ & $\begin{array}{c}\text { Limestone } \\
{[\% \text { weight }]}\end{array}$ & $\begin{array}{c}\text { Dry Hydrate } \\
{[\% \text { weight] }}\end{array}$ \\
\hline ADK1 & 62 & - & 38 \\
\hline ADK2 & 53 & 40 & 7 \\
\hline ADK3 & 50 & 50 & - \\
\hline
\end{tabular}

Table 2: $\quad$ Basic technological analysis of sludge modified for addition.

\begin{tabular}{|l|l|l|l|l|l|l|l|l|l|l|}
\hline \multirow{2}{*}{$\begin{array}{l}\text { Sample } \\
\text { descr. }\end{array}$} & $\mathrm{W}^{\mathrm{a}}$ & $\mathrm{W}_{\mathrm{t}}^{\mathrm{r}}$ & $\mathrm{A}^{\mathrm{r}}$ & $\mathrm{A}^{\mathrm{d}}$ & $\mathrm{Q}_{\mathrm{s}}{ }^{\mathrm{d}}$ & $\mathrm{Q}_{\mathrm{s}}{ }^{\text {daf }}$ & $\mathrm{Q}_{\mathrm{i}}{ }^{\mathrm{d}}$ & $\mathrm{Q}_{\mathrm{i}}{ }^{\mathrm{d}}$ & $\mathrm{Q}_{\mathrm{i}}{ }^{\text {daf }}$ & $\mathrm{S}^{\mathrm{d}}$ \\
\cline { 2 - 11 } & $\%$ & $\%$ & $\%$ & $\mathrm{MJ} / \mathrm{kg}$ & $\mathrm{MJ} / \mathrm{kg}$ & $\mathrm{MJ} / \mathrm{kg}$ & $\mathrm{MJ} / \mathrm{kg}$ & $\mathrm{MJ} / \mathrm{kg}$ & $\%$ \\
\hline ADK 1 & 5,09 & 19,65 & 50,68 & 62,84 & 4,62 & 12,42 & 2,89 & 4,23 & 11,39 & 0,46 \\
\hline ADK 2 & 3,19 & 26,47 & 39,46 & 53,67 & 3,89 & 8,38 & 2,02 & 3,64 & 7,86 & 0,36 \\
\hline ADK 3 & 3,26 & 28,30 & 38,12 & 53,16 & 3,36 & 7,17 & 1,56 & 3,16 & 6,76 & 0,44 \\
\hline
\end{tabular}

Table 3: $\quad$ Properties of modified sludge for addition.

\begin{tabular}{|l|c|c|c|c|c|c|c|c|}
\hline \multirow{2}{*}{ Sample } & $\mathbf{C}^{\text {daf }}$ & $\mathbf{H}^{\text {daf }}$ & $\mathbf{N}^{\text {daf }}$ & $\mathbf{O}^{\text {daf }}$ & $\mathbf{S}^{\text {daf }}$ & $\mathbf{C O}_{2}$ & $\begin{array}{c}\text { CaO } \\
\text { free in solid }\end{array}$ & $\begin{array}{c}\text { Carbonates } \\
\text { in solid }\end{array}$ \\
\cline { 2 - 8 } & $\%$ & $\%$ & $\%$ & $\%$ & $\%$ & $\%$ & $\%$ & $\%$ \\
\hline ADK 1 & 31,81 & 4,74 & 2,74 & 59,47 & 1,24 & $<0,01$ & 36,88 & 1,62 \\
\hline ADK 2 & 36,00 & 2,38 & 2,22 & 58,62 & 0,78 & $<0,01$ & 6,08 & 22,30 \\
\hline ADK 3 & 34,48 & 1,90 & 2,16 & 60,52 & 0,94 & 3,19 & 4,01 & 10,00 \\
\hline
\end{tabular}




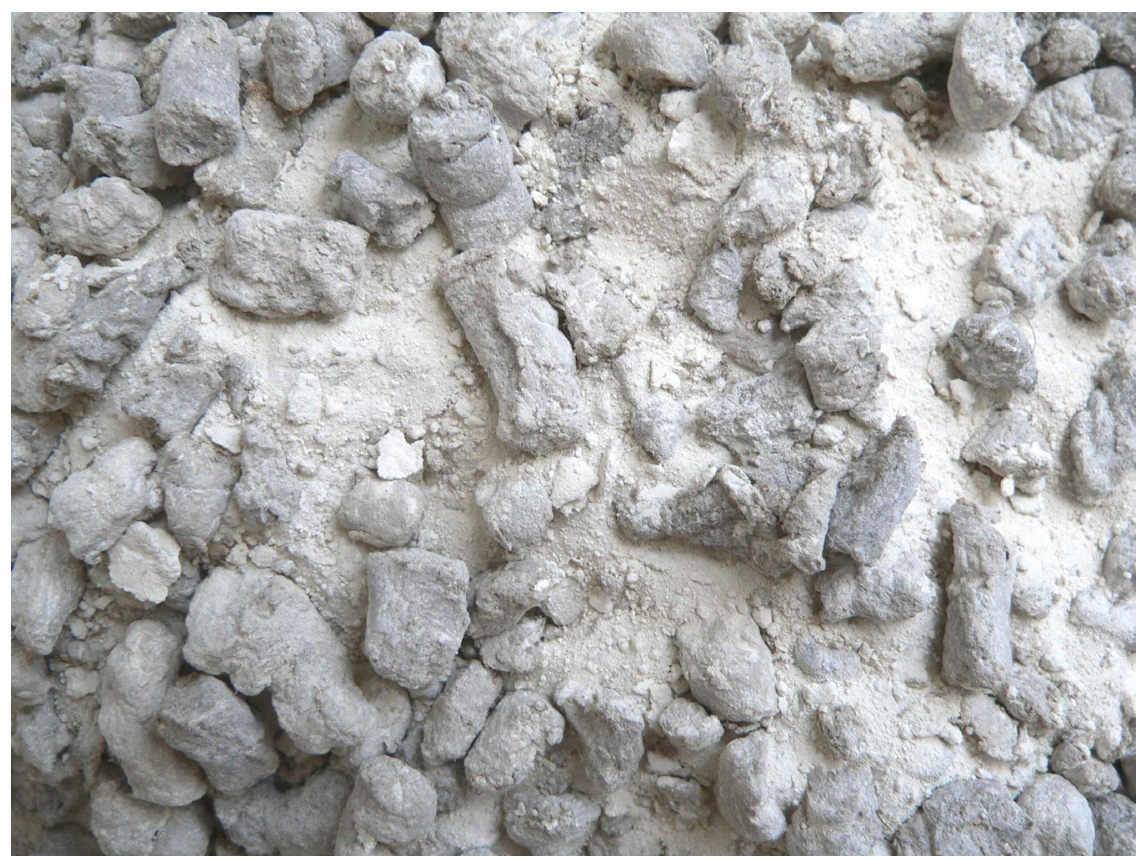

Figure 1: $\quad$ Prepared sample ADK2.

\section{Laboratory verification of effectiveness of new additives}

It is possible to verify the effectiveness of desulphurization additives by practical tests of coal burning in an industrial facility for which the additive is specified. Such tests are quite expensive and often also require careful management. In order to compare the effectiveness of different additives and to check the optimum amount of the additive to achieve the necessary grade of desulphurization, it is possible to use a model burning test using a smaller sample amount. The efficiency of the additive at a given concentration can easily be determined by finding out the sulphur content in the ash produced by burning the sample under certain conditions. In this way the additives can be compared from an efficiency point of view, but their optimum consumption can also be guessed (i.e. optimum ratio of the additive and coal of certain quality). If the laboratory conditions are similar to real conditions, especially the temperature at which the processes are taking place, the results of desulphurization can be used for the prediction of additive behavior under real conditions. A similar principle of desulphurization condition modeling was successfully applied to compare the desulphurization of various types of additives in the past.

\subsection{Sample preparation for verification}

First of all homogenization and adjustment of all input materials was made for additive adding to a granularity of less than $0.2 \mathrm{~mm}$. For modified samples, 
parameters were set which are needed to determine the efficiency according to the methodology of accredited labs of the Brown Coal Research Institute, j.s.c. The results of analyses made are shown in the Table 4.

Table 4: $\quad$ Analysis results of samples for lab burning tests.

\begin{tabular}{|c|c|c|c|c|c|c|c|c|c|c|}
\hline \multirow{2}{*}{ Sample } & $\mathrm{W}^{\mathrm{a}}$ & $\mathrm{W}_{\mathrm{t}}^{\mathrm{r}}$ & $\mathrm{A}^{\mathrm{r}}$ & $\mathrm{A}^{\mathrm{d}}$ & $\mathrm{Q}_{\mathrm{s}}^{\mathrm{d}}$ & $\mathrm{Q}_{\mathrm{s}}^{\mathrm{daf}}$ & $\mathrm{Q}_{\mathrm{i}}^{\mathrm{r}}$ & $\mathrm{Q}_{\mathrm{i}}^{\mathrm{d}}$ & $\mathrm{Q}_{\mathrm{i}}^{\mathrm{daf}}$ & $S^{d}$ \\
\hline & $\%$ & $\%$ & $\%$ & $\%$ & $\mathrm{MJ} / \mathrm{kg}$ & $\mathrm{MJ} / \mathrm{kg}$ & $\mathrm{MJ} / \mathrm{kg}$ & $\mathrm{MJ} / \mathrm{kg}$ & $\mathrm{MJ} / \mathrm{kg}$ & $\%$ \\
\hline M-1 & 6,16 & 23,82 & 18,67 & 25,38 & 23,05 & 30,89 & 15,59 & 22,09 & 29,60 & 1,43 \\
\hline M-2 & 6,13 & 26,98 & 17,03 & 23,32 & 23,66 & 30,86 & 15,81 & 22,57 & 29,44 & 1,29 \\
\hline M-3 & 6,02 & 27,38 & 16,91 & 23,29 & 23,80 & 31,03 & 15,82 & 22,71 & 29,61 & 1,39 \\
\hline M-4 & 4,69 & 25,56 & 19,99 & 26,86 & 21,61 & 29,54 & 14,77 & 20,70 & 28,30 & 1,41 \\
\hline M-5 & 5,84 & 26,17 & 18,20 & 24,65 & 22,86 & 30,34 & 15,52 & 21,90 & 29,07 & 1,45 \\
\hline M-6 & 4,79 & 26,87 & 16,75 & 22,91 & 23,74 & 30,79 & 16,62 & 22,72 & 29,47 & 1,51 \\
\hline M-7 & 4,34 & 23,23 & 21,78 & 28,37 & 19,81 & 27,66 & 13,98 & 18,96 & 26,47 & 1,11 \\
\hline M-8 & 4,27 & 23,98 & 20,98 & 27,60 & 20,46 & 28,25 & 14,30 & 19,60 & 27,07 & 1,25 \\
\hline M-9 & 4,30 & 24,62 & 19,97 & 26,49 & 21,31 & 28,98 & 14,75 & 20,38 & 27,73 & 1,25 \\
\hline M-10 & 4,35 & 26,38 & 18,05 & 24,52 & 22,69 & 30,06 & 15,99 & 21,72 & 28,77 & 1,29 \\
\hline M-11 & 4,58 & 27,16 & 16,92 & 23,23 & 23,59 & 30,73 & 15,85 & 22,70 & 29,56 & 1,28 \\
\hline M-12 & 4,62 & 27,43 & 16,37 & 22,56 & 23,91 & 30,88 & 15,90 & 22,86 & 29,52 & 1,35 \\
\hline M-13 & 4,63 & 29,28 & 11,63 & 16,44 & 26,32 & 31,50 & 17,11 & 25,22 & 30,19 & 1,44 \\
\hline
\end{tabular}

Based on the comparison of information about additive used so far and previously tried additive which is limestone from Č́žkovice and information about the modified sludge from wastewater treatment plant, recipes of samples for lab burning tests were suggested. With every newly-checked additive (ADK1 to ADK3), three samples were always prepared, each with a different ratio of additive to coal. For comparison three samples were prepared with previouslytried additive, i.e. Č́źǩkovice limestone. For comparison, another coal sample without additive was prepared. For every recipe, ash fusibility was determined for control in order to ascertain the influence of the additive amount to possible sintering of additive samples. Recipes of the samples are again shown in Table 5.

\subsection{Lab burning tests}

The prepared samples were analyzed and model lab burning of analytic sample with known input chemical composition was done at a temperature of approximately $850^{\circ} \mathrm{C}$. This temperature is achieved when burning coal in a fluid boiler.

The samples with additives which were prepared according to recipes were burnt in a muffle furnace under controlled conditions at a temperature of $850^{\circ} \mathrm{C}$ until it attained a constant weight. The partial samples with additive were at first dried in an oven at $105-110^{\circ} \mathrm{C}$ until they attained a constant weight. The dried samples with additive were annealed in a muffle furnace at $850^{\circ} \mathrm{C}$ with gradient rise of temperature and time pause $\left(30 \mathrm{~min}\right.$.) at $700^{\circ} \mathrm{C}$. Total annealing time of samples with additive was 10 hours. After annealing and ash cooling-down, a visual check of unburned particles was made. At the same time, the loss caused 
by annealing of every sample with additive was determined. In the ash, the total content of sulphur $\mathrm{S}_{\mathrm{t}}^{\mathrm{d}}$ by method Eschka acc. to $\breve{C} \mathrm{SN} 441379$ was determined. These are the results of theoretical desulphurization level.

\section{Desulphurization efficiency calculation procedure}

If there is a reaction as a result of additive being checked with sulphur dioxide being created, calcium sulphate is produced, which is bound in the ash. From sulphur concentration in ash produced by burning samples and other information, it is possible to determine how many per cent of sulphur were released into the air and how much was bound into the ash. This shows desulphurization efficiency of additive under set conditions. If no sulphur was bound into the ash, the efficiency is zero and all sulphur released by burning comes into the combustion gas. If, on the contrary, all the sulphur stays in the ash, no sulphur dioxide would be released into the air and desulphurization efficiency would be $100 \%$.

The calculated values of desulphurization efficiency are shown in Table 5. From the desulphurization efficiency values, it is obvious that all used additives desulphurize effectively in the suitably-selected dosing ratio under set lab conditions. In spite of the fact that certain efficiency variances were observed, it can be said that the desulphurization efficiency achieved at maximum used additive was about $64 \%$ in one case and in other cases equal or higher than $68 \%$ which means that about two-thirds of the created amount of sulphur dioxide can be bound by the added additive into the ash. In case of burning the sample of pure coal a part of sulphur (approximately 4\%) combined with alkalic components $(\mathrm{CaO}, \mathrm{MgO})$ contained in the ash (so called self- desulphurization).

Table 5: Desulphurization efficiency found out at lab tests.

\begin{tabular}{|c|c|c|c|c|}
\hline Sample & $\begin{array}{c}\text { Weight part } \\
\text { [Coal Hp2] } \\
{[\%]}\end{array}$ & $\begin{array}{l}\text { Type of } \\
\text { additive }\end{array}$ & $\begin{array}{c}\text { Weight part } \\
\text { of additive } \\
{[\%]}\end{array}$ & $\begin{array}{c}\text { Desulphurizatio } \\
\text { n efficiency } \\
{[\%]}\end{array}$ \\
\hline M-1 & 100 & ADK1 & 10 & 68,0 \\
\hline M-2 & 100 & ADK1 & 8 & 85,0 \\
\hline M-3 & 100 & ADK1 & 6 & 69,0 \\
\hline M-4 & 100 & ADK2 & 15 & 63,9 \\
\hline M-5 & 100 & ADK2 & 12,5 & 69,7 \\
\hline M-6 & 100 & ADK2 & 10 & 59,9 \\
\hline M-7 & 100 & ADK3 & 30 & 71,4 \\
\hline M-8 & 100 & ADK3 & 25 & 55,4 \\
\hline M-9 & 100 & ADK3 & 20 & 65,9 \\
\hline M-10 & 100 & ČÍŽK. VÁP & 10 & 73,2 \\
\hline M-11 & 100 & ČÍŽK. VÁP & 8 & 70,6 \\
\hline M-12 & 100 & ČÍŽK. VÁP & 6 & 61,1 \\
\hline M-13 & 100 & ŽÁDNÉ & 0 & 4,1 \\
\hline
\end{tabular}




\section{Conclusion}

In terms of this study there was laboratory checked activity of new desulphurization additives. The new additives were prepared based on the sludge from wastewater treatment plants stabilized by adding components containing limy ions (dry hydrate or limestone). After stabilizing the sludge shows heating power in original state according to a recipe approximately 1.5 to $2.9 \mathrm{MJ} / \mathrm{kg}$. In terms of lab burning tests, the desulphurization activity of the additives is comparable today with Čížkovice limestone. It can be assumed that to substitute the amount of this limestone for desulphurization completely at fluid burning, it would be possible to use the same amount of additive ADK1 or approximately for $50 \%$ more additive ADK2 or three times the amount of ADK3. Sludges from wastewater treatment plants are often placed in depots. The results of this study show that after stabilizing sludge by adding limy ions, there is the possibility that such modified sludge can also be used for industrial use as substitute for limestone that is currently used at fluid burning of brown coal. The implementation of the results of this study makes it possible in reality to use potential waste, which would otherwise be thrown to a depot. At the same time, the energy contained in the sludge of a wastewater treatment plant would be used as well. This fulfills the requirement of these days - that is to say, using waste for making energy rather than throwing it in a depot.

\section{Acknowledgements}

This study was made in terms of research work of Research Center 1M06007 "Research center of integrated system of using auxiliary products of mining, modification and processing energy base materials" in support of and contribution from the Ministry of Education, Youth and Physical Education of the Czech Republic.

\section{References}

[1] Sedláček, P., Fečko, P., Valeš, J., Čablík, V., Martinek, T.: Verification of theoretical calculation for reduction of $\mathrm{SO}_{2}$ emissions upon production of brown-coal pellets, Sborník: 7th Conference of Environment and Mineral Processing, VŠB-TU Ostrava 26.6.-28.6.2003, s.355-358, ISBN 80-2480248-1

[2] Valeš, J., Sedláček, P.: Zajištění, provedení a vyhodnocení spalovacích zkoušek aditivovaného paliva (hp, trríděné druhy) na vybraných průmyslových spotřebičích (Děčín, Bezdružice) - TR8 050, Technická zpráva VÚHU a.s., 1999

[3] Sedláček, P., Valeš, J., Šafářová, M., Riedlová, S.: Potential production of ecological pellets with biomass or wastes, 5. European Conference Coal Research and its Applications, 6th - 8th September 2004, Edinburgh, Scotland 
826 Management of Natural Resources, Sustainable Development and Ecological Hazards

[4] Roubíček, V., Buchtele, J.: Uhlí - zdroje, procesy, užití, Ostrava 2002, Sborník: 6th Conference on Environment and Mineral Processing, part II, s.797-802, ISBN 80-248-0072-1 (Coal-sources, Processes, Utilisation, Ostrava 2002, Collection)

[5] Vidlář J., Hodek, O.: Základy úpravy užitkových surovin, I. A II. Díl, VŠB Ostrava, Most 1984 